\title{
PRINSIP GENERAL TAKAFUL SYSTEM DALAM AKAD ASURANSI SYARIAH DEMI MENCAPAI KEMASLAHATAN
}

\author{
Hilda Yunita Sabrie \\ Prawitra Thalib \\ Amalia Rizki \\ Fakultas Hukum Universitas Airlangga Surabaya \\ e-mail: hilda_sabrie@yahoo.co.id, prawitra_3688@yahoo.com,riskyamalia07@gmail.com
}

\begin{abstract}
ABSTRAK
Perkembangan industri asuransi di Indonesia makin berkembang, hal ini dapat dilihat dari makin meningkatnya kesadaran masyarakat untuk ikut berasuransi. Menangkap peluang tersebut, maka saat ini banyak perusahaan asuransi bermunculan dengan menawarkan banyak produk dan jenis asuransi yang kompetitif. Asuransi syariah menjadi salah satu pilihan masyarakat yang dianggap sangat diminati karena dianggap lebih baik daripada asuransi konvensional. Dalam praktiknya perusahaan asuransi tidak semuanya memahami prinsip-prinsip dasar asuransi syariah sehingga pada praktiknya tidak sesuai dengan prinsip-prinsip tersebut. Untuk itu perlu ada kajian yang lebih dalam terkait dengan teknis dan prinsip asuransi syariah yang saat ini dijalankan oleh perusahaan-perusahaan asuransi syariah. Maka perlu diketahui pula oleh para nasabah, calon nasabah dan terutama perusahaan asuransi syariah mengenai prinsip General Takaful System (GTS). Diharapkan perusahaan tersebut benar-benar menjalankan prinsip asuransi syariah sesuai dengan Al-Quran, Hadist dan Peraturan Perundang-undangan yang berlaku di Indonesia agar tercapai kesejahteraan bersama.
\end{abstract}

Kata Kunci: asuransi syariah, prinsip-prinsip asuransi syariah, perusahaan asuransi syariah, prinsip GTS.

\begin{abstract}
The development of insurance industry in Indonesia is growing, it can be seen from the increasing awareness of the public to participate in insurance. Capturing these opportunities, then the current many insurance companies have sprung up to offer a lot of products and competitive insurance types. Takaful be one of the people who are considered highly desirable because it is considered better than conventional insurance. In practice, insurance companies do not all understand the basic principles of Islamic insurance so that in practice is not in accordance with these principles. For that there needs to be a deeper study related to the technical principles of Islamic insurance which is currently run by insurance companies'sharia. Then it needs to be known also by its customers, prospective customers and especially the Islamic insurance company regarding the principle of General Takaful System (GTS). It is expected that the company is actually running the principles of Islamic insurance in accordance with the Al-Qur'an, Hadist and legislations in force in Indonesia in order achieve common prosperity. Keywords: takaful, principles of takaful, islamic insurance company, GTS principles.
\end{abstract}

\section{PENDAHULUAN}

Asuransi syariah merupakan usaha saling melindung dan saling menolong di antara sejumlah orang atau pihak melalui investasi dalam bentuk aset dan atau tabarru' yang memberikan pola pengembalian untuk menghadapi resiko tertentu melalui akad (perikatan) yang sesuai dengan syariah. ${ }^{1}$ Asuransi syariah merupakan salah satu sistem ekonomi berbasis Islam yang bersifat universal dan berlaku

\footnotetext{
1 Kuat Ismanto, Asuransi Syariah (Tinjauan Asas-Asas Hukum Islam), Pustaka Pelajar, Yogyakarta, 2009, h. 2.
} 
untuk semua keyakinan dan golongan masyarakat. Asuransi syariah tidak mengandung hal-hal seperti ketidakpastian, perjudian, riba, penganiayaan, suap, barang haram, dan maksiat.

Asuransi syariah dapat juga disebut asuransi ta'awun yang artinya tolong-menolong atau saling membantu. Oleh karena itu dapat dikatakan bahwa asuransi ta'awun prinsip dasarnya adalah dasar syariat yang saling toleran terhadap sesama manusia untuk menjalin kebersamaan dalam meringankan bencana yang dialami peserta. Prinsip ini sesuai dengan firman Allah SWT dalam Surat Al-Maidah ayat 2, yang artinya, Dan saling tolong-menolonglah dalam kebaikan dan ketaqwaan dan jangan saling tolong-menolong dalam dosa dan permusuhan.

Asuransi ditinjau dari bentuknya dibagi menjadi dua yaitu asuransi Takaful atau Ta'awun (at-Ta'min at-Ta'awuni) dan Niaga (at-Ta'min at-Tijari) ini mencakup asuransi kerugian dan asuransi jiwa. Sementara menurut Peraturan Menteri Keuangan No. 18/PMK.010/2010 tentang Penerapan Prinsip Dasar Penyelenggaraan Asuransi dan Usaha Reasuransi dengan Prinsip Syariah, menegaskan bahwa Asuransi berdasarkan prinsip syariah merupakan usaha saling tolong-menolong atau ta'awuni dan melindungi atau takafuli di antara para peserta melalui pembentukan kumpulan dana atau Dana Tabarru' yang dikelola sesuai prinsip syariah untuk menghadapi risiko tertentu. Beberapa hal yang dapat digarisbawahi berkaitan dengan definisi takaful antara lain: Usaha saling tolong-menolong dan saling melindungi di antara para peserta takaful; Para peserta takaful melakukan pembentukan kumpulan dana yang disebut dengan Dana Tabarru'; Dana tabarru' dikelola sesuai dengan prinsip syariah; Pengelolaan dana tabarru dimaksudkan untuk persiapan apabila terjadi risiko di antara para peserta takaful.

Ini berarti bahwa manakala seseorang bergabung menjadi peserta takaful maka dia sudah meniatkan dirinya untuk saling tolong-menolong dan saling melindungi di antara para peserta takaful lainnya. Artinya ketika terjadi risiko pada salah satu peserta takaful maka peserta lainnya akan menolong dan akan melidungi peserta yang mendapatkan risiko tersebut.

Untuk dapat saling tolong-menolong dan saling melindungi ini, para peserta takaful melakukan penghimpunan dana yang disebut dana tabarru atau dana kebajikan. Dana yang terkumpul melalui akad yang sesuai dengan hukum Islam ini selanjutnya dikelola oleh perusahaan takaful. Pengelolaan dana ini pun harus sesuai dengan hukum Islam. Hasil pengelolaan dana selanjutnya digunakan sebagai pertanggungan apabila terjadi risiko pada salah satu peserta takaful. Dengan prinsip ini, jelaslah bahwa, Dana tabarru sepenuhnya adalah milik peserta takaful (shohibul mal); Perusahaan takaful hanya bertindak sebagai pengelola/operator dana tabarru atau pemegang amanah (mudharib), tidak ikut dalam pertanggungan risiko; Sistem pertanggungan risiko adalah dengan cara saling share risiko; Tidak ada perpindahan risiko dari peserta kepada perusahaan takaful.

Berdasarkan latar belakang yang telah diuraikan di atas, maka yang menjadi permasalahan dalam penulisan ini, pengertian dari General Takaful System (yang selanjutnya disebut GTS) dan karakteristik akad asuransi syariah yang mengandung prinsip GTS demi mewujudkan kemaslahatan dalam praktik perasuransian syariah?

\section{Pengertian Prinsip General Takaful System Sebagai Bentuk Perwujudan Kemaslahatan}

Masyarakat Indonesia yang mayoritas beragama Islam menyebabkan perlunya asuransi syariah untuk memenuhi kebutuhan. Dalam kehidupan kontemporer sekarang, khususnya tiga dasawarsa terakhir, hukum Islam terutama di bidang keperdataan atau mu'amalah semakin mempunyai arti penting, terutama dengan lahirnya apa yang disebut dengan ekonomi, perbankan dan asuransi yang sangat erat kaitannya dengan hukum mu'amalat. ${ }^{2}$ Adanya kebutuhan masyarakat terhadap asuransi syariah membuat asuransi syariah mengalami perkembangan. Hingga banyak dijumpai saat ini perusahaan asuransi yang menawarkan produk asuransi syariah. Hal ini selaras dengan kebutuhan masyarakat Islam yang menginginkan berasuransi dengan prinsip general takaful yang di dalam prinsip tersebut terkandung asas-asas umum untuk melakukan kegiatan asuransi syariah.

Adapun landasan hukum asuransi syariah berdasarkan Al-Qur'an sebagai dasar utama dan Al-Hadist. Prinsip utama dalam asuransi syariah yaitu terhindar dari unsur gharar, maisir dan riba' berdasarkan syariat Islam dengan mengacu kepada Al-Qur'an dan Al-Hadist. Hal inilah yang tidak diatur

\footnotetext{
${ }^{2}$ Kuat Ismanto, Asuransi Syariah (Tinjauan Asas-Asas Hukum Islam), Pustaka Pelajar, 2009, h. 2.
} 
dalam asuransi berdasarkan Kitab Undang-Undang Hukum Dagang (yang selanjutnya disebut KUHD), tetapi dalam asuransi syariah hal tersebut telah diatur dalam Al-Qur'an dan Al-Hadist. Pengaturan mengenai asuransi syariah dalam Al-Qur'an bersifat terbuka artinya Allah SWT hanya memberikan aturan yang bersifat garis besarnya saja, selebihnya adalah terbuka bagi mujtahid untuk mengembangkannya melalui pemikian-pemikirannya selama hal tersebut tidak bertentangan dengan Al-Qur'an dan Al-Hadist.

Konsep asuransi tidak disebutkan secara eksplisit dalam Al-Qur'an namun hal tersebut dapat diklasifikasikan menjadi empat macam kategori, yaitu: ${ }^{3}$

Pertama, Perintah Allah untuk mempersiapkan masa depan, terdapat dalam Q.S. Al-Hasyr ayat 18, yang artinya, Hai orang-orang yang beriman, bertakwalah kepada Allah dan hendaklah setiap diri memperhatikan apa yang dibuat untuk hari esok (masa depan). Dan bertakwalah kepada Allah, sesungguhnya Allah Maha Mengetahui apa yang kamu kerjakan; Dan terdapat dalam Q.S. Yusuf ayat $47-49$, yang artinya Yusuf berkata, supaya kamu bertanam tujuh tahun lamanya sebagaimana biasa. Maka, apa yang kamu tuai hendaklah kamu biarkan dibulirnya kecuali sedikit untuk kamu makan. Kemudian sesudah itu akan datang tujuh tahun yang amat sulit yang menghabiskan apa yang kamu simpan untuk menghadapinya (tahun sulit), kecuali sedikit dan (bibit gandum) yang kamu simpan. Kemudian akan datang tahun padanya manusia diberi hujan (dengan cukup) dan di masa itu mereka memeras anggurnya.

Kedua, Perintah Allah untuk saling tolongmenolong dan bekerjasama, terdapat dalam: (1) Q.S. Al-Maidah ayat 2, yang artinya tolong-menolonglah kamu dalam (mengerjakan) kebaikan dan takwa dan jangan tolong-menolong dalam berbuat dosa dan pelanggaran. Dan bertakwalah kamu kepada Allah, sesungguhnya Allah amat berat siksa-Nya, dan terdapat dalam Q.S. Al-Baqarah ayat 185, yang artinya Allah menghendaki kemudahan bagimu, dan tidak menghendaki kesukaran bagimu.

Ketiga, Perintah Allah untuk saling melindungi antar sesama ketika menghadapi kesusahan, terdapat dalam Q.S. Al-Quraisiy ayat 4, yang artinya, yang telah memberi makanan kepada mereka untuk

\footnotetext{
3 Abdul Ghofur, Anshori, Asuransi Syariah di Indonesia, UII Press, Yogyakarta, 2008, h. 29.
}

menghilangkan lapar dan mengamankan mereka dari ketakutan, dan terdapat dalam Q.S. Al-Baqarah ayat 126, yang artinya, Dan ketika Ibrahim berdoa, Ya Tuhanku, jadikanlah negeri ini yang aman sentosa dan selamat.

Keempat, Perintah Allah untuk bertawakal dan optimis dalam berusaha, terdapat dalam Q.S. AlTaghnaabun ayat 11, yang artinya Tidak ada sesuatu musibah pun yang menimpa seseorang kecuali dengan izin Allah, dan terdapat dalam Q.S. Luqman ayat 34 , yang artinya Sesungguhnya Allah, hanya pada sisi-Nya sajalah pengetahuan tentang hari kiamat, dan Dialah yang menurunkan hujan, dan mengetahui apa yang ada dalam rahim. Dan, tidak seorang pun yang dapat mengetahui dengan pasti apa yang akan diusahakannya besok, dan tiada seorang pun yang dapat mengetahui di bumi mana ia akan mati. Sesungguhnya Allah Maha Mengetahui lagi Maha Mengenal.

Dasar-dasar tersebut yang dijadikan landasan hukum asuransi syariah, dimana konsep megenai asuransi tersebar dalam ayat-ayat di Al-Qur'an. Selain itu, konsep asuransi juga dapat dilihat dalam Hadist Nabi Muhammad SAW, yaitu:

Pertama, Hadist tentang Aqilah, diriwayatkan oleh abu Hurairah r.a., menyatakan bahwa Berselisih dua orang wanita dari suku Huzail, kemudian salah satu wanita tersebut melempar batu ke wanita yang lain sehingga mengakibatkan kematian wanita tersebut beserta janin yang dikandungnya. Maka ahli waris dari wanita yang meninggal tersebut mengadukan peristiwa tersebut kepada Rasulullah SAW, maka Rasulullah SAW memutuskan ganti rugi dari pembunuhan terhadap janin tersebut dengan pembebasan seorang budak laki-laki atau perempuan, dan memutuskan ganti rugi kematian wanita tersebut dengan uang darah atau diyat yang dibayarkan oleh aqilahnya atau kerabat dari orangtua laki-lak. (HR. Bukhari)

Kedua, Hadist tentang Anjuran Menghilangkan Kesulitan Seseorang, yang diriwayatkan oleh Abu Hurairah r.a, Nabi Muhammad bersabda bahwa barangsiapa yang menghilangkan kesulitan duniawinya seorang mukmin, maka Allah SWT akan menghilangkan kesulitannya pada hari kiamat. Barangsiapa yang mempermudah kesulitan seseorang maka Allah akan mempermudah urusannya di dunia dan akhirat. (HR. Muslim) 
Ketiga, Hadist tentang Menghindari Risiko, yang diriwayatkan dari Anas bin Malik r.a, bertanya seseorang kepada Rasulullah SAW, tentang (untanya) bahwa, Apa (unta) ini saya ikat saja atau langsung saya bertawakal pada (Allah SWT)? Bersabda Rasulullah SAW, Pertama ikatlah unta itu kemudian bertawakal kepada Allah SWT. (HR. At-Tumudzi)

Keempat, Hadist tentang Saling Mengasihi dan Berbelas Kasih, yang diriwayatkan dari Nu'man bin Basyir, Nabi Muhammad SAW bersabda bahwa, Engkau akan menyaksikan Kaum Mu'minin dengan kasih sayang, belas kasih dan kelembutan sesamanya, bagaikan sebatang tubuh. Apabila salah satu bagian dari tubuh mengeluh, maka mengeluhlah seluruh tubuhnya, tidak dapat tidur dan kepanasan. (HR. Ahmad)

Berdasarkan hadist-hadist tersebut dapat dilihat bahwa di dalam Islam konsep asuransi pun dikenal. Selain itu, dalam Piagam Madinah juga dikenal mengenai sistem aqilah. Manfaat dari sistem aqilah ini adalah mempertahankan keseimbangan kesukuan sehingga kekuatan pembalasan dendam dari setiap suku dapat menghalangi kekejaman anggota suku lain, menambah sebagian besar jaminan sosial, karena mengingat tanggung jawab kolektif untuk membayar ganti rugi sehingga setiap anggota suku harus menjaga seluruh kegiatan anggotanya dengan seksama, mengurangi beban anggota perorangan jika ia harus membayar ganti rugi, menghindarkan dendam darah yang jika tidak dicegah akan mengakibatkan kehancuran total suku-suku yang terlibat, serta mempertahankan sepenuhnya kesatuan dan kerjasama para anggota dari setiap suku, yang tak lain merupakan mutualitas (saling membantu). ${ }^{4}$

Penyelenggaraan asuransi syariah bersumber utama pada Al-Qur'an dan Al-Hadist, di samping itu penyelenggaraan asuransi syariah juga harus mengacu pada Undang-Undang Nomor 40 Tahun 2014 tentang Perasuransian dan harus diperhatikan beberapa Keputusan Menteri Keuangan Republik Indonesia Nomor 422/KMK.06/2003 tentang Penyelenggaraan Usaha Perusahaan Asuransi dan Perusahaan Reasuransi, Keputusan Menteri Keuangan Republik Indonesia Nomor 424/KMK.06/2003 tentang Kesehatan Keuangan Perusahaan Asuransi dan Perusahaan Reasuransi, dan Keputusan Menteri Keuangan Republik Indonesia Nomor

\footnotetext{
${ }^{4}$ Muhammad Muslehuddin, Menggugat Asuransi Modern, Lentera, Jakarta, 1999, h. 31.
}

426/KMK.06/2003 tentang Perizinan Usaha dan Kelembagaan Perusahaan Asuransi dan Perusahaan Reasuransi. Setiap perusahaan asuransi yang menawarkan asuransi syariah harus mengacu pada ketentuan-ketentuan tersebut.

Asuransi Syariah memiliki prinsip yang berbeda dengan lembaga konvensional. Prinsip-prinsip tersebut antara lain: ${ }^{5}$

Pertama, Tauhid, merupakan prinsip dasar dalam asuransi syariah. Karena pada hakikatnya setiap muslim harus melandasi dirinya dengan tauhid dalam menjalankan segala aktivitas kehidupannya, tidak terkecuali dalam bermuamalah. Artinya bahwa niatan dasar ketika berasuransi syariah haruslah berlandaskan pada prinsip tauhid, yaitu mengharapkan keridhaan Allah SWT. Sebagai contoh dilihat dari sisi perusahaan, asas yang digunakan dalam berasuransi syariah bukanlah semata-mata meraih keuntungan, atau menangkap peluang pasar yang sedang cenderung pada syariah. Namun lebih dari itu, niatan awalnya adalah untuk mengimplementasikan nilai-nilai syariah dalam dunia asuransi. Sedangkan dari sisi nasabah, berasuransi syariah adalah bertujuan untuk bertransaksi dalam bentuk tolong menolong yang berlandaskan asas syariah, dan bukan semata-mata mencari perlindungan apabila terjadi musibah. Dengan demikian, maka nilai tauhid terimplementasikan pada industri asuransi syariah. Allah SWT berfirman yang artinya, Dan tidaklah Aku menciptakan jin dan manusia, melainkan supaya mereka menyembahKu. (QS. Adh-Dhariyat: 56).

Kedua, Saling Membantu dan Bekerjasama. Semangat tolong-menolong merupakan aspek yang sangat penting dalam operasional asuransi syariah. Karena pada hakikatnya, konsep asuransi syariah didasarkan pada prinsip ini. Dimana sesama peserta bertabarru' atau berderma untuk kepentingan nasabah lainnya yang tertimpa musibah. Nasabah tidaklah berderma kepada perusahaan asuransi syariah, peserta berderma hanya kepada sesama peserta saja. Perusahaan asuransi syariah bertindak sebagai pengelola saja. Konsekuensinya, perusahaan tidak berhak mengklaim atau mengambil dana tabarru' nasabah. Perusahaan hanya mendapatkan dari ujrah atau fee atas pengelolaan dana tabarru' tersebut, yang dibayarkan oleh nasabah bersamaan dengan pembayaran kontribusi atau premi. Perusahaan

${ }^{5}$ Buku Saku Lembaga Bisnis Syariah, Pusat Komunikasi Ekonomi Syariah (PKES). 
asuransi syariah mengelola dana tabarru' tersebut, untuk diinvestasikan secara syariah lalu kemudian dialokasikan pada nasabah lainnya yang tertimpa musibah. Konsep ini berarti antara sesama nasabah telah mengimplementasikan saling tolong-menolong, meskipun antara mereka tidak saling bertatap muka. Allah SWT berfirman yang artinya bahwa, dan bertolong menolonglah kalian dalam kebaikan dan ketakwaan, dan janganlah kalian bertolong menolong dalam perbuatan dosa dan permusuhan (QS. AlMaidah: 2); Allah senantiasa menolong hamba-Nya selama ia menolong sesamanya (HR. Abu Daud); Barangsiapa yang memenuhi kebutuhan saudaranya, Allah akan memenuhi kebutuhannya (HR. Bukhari, Muslim, dan Abu Daud).

Ketiga, Saling melindungi dari berbagai macam kesusahan seperti membiarkan uang menganggur dan tidak berputar dalam transaksi yang bermanfaat bagi masyarakat umum. Sebagaimana firman Allah SWT yang artinya, Hai orang-orang yang beriman, janganlah kamu saling memakan harta sesamamu dengan jalan yang batil, kecuali dengan jalan perniagaan yang berlaku dengan suka sama suka di antara kamu (QS. 4:29).

Keempat, Saling Bertanggungjawab. Saling bertanggungjawab disini adalah antara perusahaan asuransi dengan nasabah atau peserta asuransi memiliki hak dan kewajiban yang sama. Sehingga akad yang telah di setujui dapat dijalankan sesuai dengan prinsip-prinsip syariah yang telah diatur atau diuraikan sebelumnya.

Kelima, Menghindari unsur Gharar, Maisyir, dan Riba. Islam menekankan aspek keadilan, suka sama suka dan kebersamaan menghadapi menghadapi resiko dalam setiap usaha dan investasi yang dirintis. Aspek inilah yang menjadi tawaran konsep untuk menggantikan gharar, maysir, dan riba yang selama ini terjadi di lembaga konvensional. Suatu asuransi diperbolehkan secara syar'i, jika tidak menyimpang dari prinsip-prinsip dan aturan-aturan syariat Islam. Untuk itu dalam muamalah tersebut harus memenuhi ketentuan-ketentuan sebagai berikut: ${ }^{6}$ a. Asuransi syariah harus dibangun atas dasar taawun atau kerjasama, tolong-menolong, saling menjamin, tidak berorentasi bisnis atau keuntungan materi semata. Allah SWT berfirman, Dan saling tolong-menolonglah

6 http://www.hambaliislamic.co.cc, Asuransi Syariah Prinsp-Prinsip Dasar Asuransi Syariah, diakses tanggal 21 April 2015. dalam kebaikan dan ketaqwaan dan jangan saling tolong-menolong dalam dosa dan permusuhan; $b$. Asuransi syariah tidak bersifat mu'awadhoh, tetapi tabarru' atau mudharobah; c. Sumbangan (tabarru') sama dengan hibah (pemberian), oleh karena itu haram hukumnya ditarik kembali. Kalau terjadi peristiwa, maka diselesaikan menurut syariat; $d$. Setiap anggota yang menyetor uangnya menurut jumlah yang telah ditentukan, harus disertai dengan niat membantu demi menegakan prinsip ukhuwah. Kemudian dari uang yang terkumpul itu diambillah sejumlah uang guna membantu orang yang sangat memerlukan; e. Tidak dibenarkan seseorang menyetorkan sejumlah kecil uangnya dengan tujuan supaya ia mendapat imbalan yang berlipat bila terkena suatu musibah. Akan tetapi ia diberi uang jamaah sebagai ganti atas kerugian itu menurut izin yang diberikan oleh jamaah; f. Apabila uang itu akan dikembangkan, maka harus dijalankan menurut aturan syar'i.

Keenam, Keadilan, prinsip kedua yang menjadi nilai-nilai dalam pengimplementasian asuransi syariah adalah prinsip keadilan. Artinya bahwa asuransi syariah harus benar-benar bersikap adil, khususnya dalam membuat pola hubungan antara nasabah dengan nasabah, maupun antara nasabah dengan perusahaan asuransi syariah, terkait dengan hak dan kewajiban masing-masing. Asuransi syariah tidak boleh mendzalimi nasabah dengan hal-hal yang akan menyulitkan atau merugikan nasabah. Ditinjau dari sisi asuransi sebagai sebuah perusahaan, potensi untuk melakukan ketidakadilan sangatlah besar. Seperti adanya unsur dana hangus (pada saving produk), dimana nasabah yang sudah ikut asuransi (misalnya asuransi pendidikan) dengan periode tertentu, namun karena suatu hal ia membatalkan kepesertaannya di tengah jalan. Pada asuransi syariah, dana saving nasabah yang telah dibayarkan melalui premi harus dikembalikan kepada nasabah bersangkutan, berikut hasil investasinya. Bahkan terkadang asuransi syariah merasa kebingungan ketika terdapat dana-dana saving nasabah yang telah mengundurkan diri atau terputus di tengah periode asuransi, lalu tidak mengambil dananya tersebut kendati pun telah dihubungi baik melalui surat maupun melalui media lainnya. Mau dikemanakan dana ini? Karena dana tersebut bukanlah milik asuransi syariah, namun milik nasabah. Namun telah bertahun-tahun diberitahu atau dihubungi, nasabah bersangkutan tidak juga mengambilnya. Hal ini tentu berbeda dengan asuransi pada umumnya. 
Allah SWT berfirman, yang artinya Hai orang-orang yang beriman, hendaklah kamu menjadi orang-orang yang selalu menegakkan kebenaran karena Allah, menjadi saksi dengan adil. Dan janganlah sekali-kali kebencianmu terhadap suatu kaum, mendorong kamu untuk berlaku tidak adil. Berlaku adillah, karena adil itu lebih dekat kepada takwa. Dan bertakwalah kepada Allah, sesungguhnya Allah Maha Mengetahui apa yang kamu kerjakan. (QS. Al-Maidah, 5:08)

Ketujuh, Amanah, juga merupakan prinsip yang sangat penting. Karena pada hakikatnya kehidupan ini adalah amanah yang kelak harus dipertanggungjawabkan di hadapan Allah SWT. Perusahaan dituntut untuk amanah dalam mengelola dana premi. Demikian juga nasabah, perlu amanah dalam aspek resiko yang menimpanya. Jangan sampai nasabah tidak amanah dalam artian mengada-ada sesuatu sehingga yang seharusnya tidak klaim menjadi klaim yang tentunya akan berakibat pada ruginya para peserta yang lainnya. Perusahaan pun juga demikian, tidak boleh semena-mena dalam mengambil keuntungan, yang berdampak pada ruginya nasabah. Transaksi yang amanah, akan membawa pelakunya mendapatkan surga. Rasulullah SAW bersabda, Seorang pebisnis yang jujur lagi amanah, (kelak akan dikumpulkan di akhirat) bersama para nabi, shiddiqin, dan syuhada'. (HR. Turmudzi)

Kedelapan, Saling Ridha ('An Taradhin). Dalam transaksi apapun, aspek 'an taradhin atau saling meridhai harus selalu menyertai. Nasabah ridha dananya dikelola oleh perusahaan asuransi syariah yang amanah dan profesional. Perusahaan asuransi syariah ridha terhadap amanah yang diembankan nasabah dalam mengelola kontribusi (premi) mereka. Demikian juga nasabah ridha dananya dialokasikan untuk nasabah-nasabah lainnya yang tertimpa musibah, untuk meringankan beban penderitaan mereka. Dengan prinsip inilah, asuransi syariah menjadikan saling tolong-menolong memiliki arti yang luas dan mendalam, karena semuanya menolong dengan ikhlas dan ridha, bekerjasama dengan ikhlas dan ridha, serta bertransaksi dengan ikhlas dan ridha pula.

Kesembilan, Menghindari Risywah. Dalam menjalankan bisnisnya, baik pihak asuransi syariah maupun pihak nasabah harus menjauhkan diri sejauhjauhnya dari aspek risywah (sogok-menyogok atau suap-menyuap). Karena apapun dalihnya, risywah pasti akan menguntungkan satu pihak, dan pasti akan ada pihak lain yang dirugikan. Nasabah umpamanya tidak boleh menyogok oknum asuransi supaya bisa mendapatkan manfaaat (klaim). Atau sebaliknya perusahaan tidak perlu menyogok supaya mendapatkan premi (kontribusi) asuransi. Namun semua harus dilakukan secara baik, transparan, adil dan dilandasi dengan ukhuwah islamiyah. Islam menekankan aspek keadilan, suka sama suka dan kebersamaan menghadapi risiko dalam setiap usaha dan investasi yang dirintis. Aspek inilah yang menjadi tawaran konsep untuk menggantikan gharar, maysir, dan riba yang selama ini terjadi di lembaga konvensional.

Uraian mengenai prinsip-prinsip tersebutlah yang menjadi perhatian pokok dalam tulisan ini. Dalam praktiknya, kesembilan unsur tersebut tidaklah diterapkan secara keseluruhan, namun yang menjadi pokok dalam penyelenggaraan asuransi syariah tersebut yaitu: ${ }^{7}$

Pertama, Saling bertanggungjawab, yang berarti para peserta asuransi syariah memiliki rasa tanggung jawab bersama untuk membantu dan menolong peserta lain yang mengalami musibah atau kerugian dengan niat ikhlas, karena memikul tanggung jawab dengan niat ikhlas adalah ibadah. Rasa tanggung jawab terhadap sesama merupakan kewajiban setiap muslim, yang tentu lahir dari sifat saling menyayangi, mencintai, saling membantu dan merasa mementingkan kebersamaan untuk mendapatkan kemakmuran bersama dalam mewujudkan masyarakat yang beriman, takwa dan harmonis serta tidak mementingkan kepentingan diri sendiri semata tetapi juga mementingkan orang lain atau masyarakat.

Kedua, Saling bekerja sama atau saling membantu/tolong-menolong, yang berarti di antara peserta asuransi syariah yang satu dengan yang lainnya saling bekerja sama dan saling tolongmenolong dalam mengatasi kesulitan yang dialami karena musibah yang dideritanya. Dengan prinsip ini, maka asuransi syariah merealisir perintah Allah SWT dalam Al-Qur'an tentang kewajiban hidup bersama dan saling menolong di antara sesama umat manusia.

Ketiga, Saling melindungi penderitaan satu sama lain, yang berarti bahwa para peserta asuransi syariah akan berperan sebagai pelindung bagi peserta lain yang mengalami gangguan keselamatan berupa musibah

\footnotetext{
${ }^{7}$ Gemala Dewi, Aspek-aspek Hukum dalam Perbankan dan Perasuransian Syariah di Indonesia, Kencana, Jakarta, 2004.
} 
yang dideritanya. Untuk itulah, dalam menjalankan usaha asuransi syariah, juga sangat diperlukan tegaknya nilai-nilai syariah, agar operasional asuransi syariah benar-benar mencerminkan ruh syariah yang sesungguhnya. Jika hal tersebut dapat diwujudkan atau diaplikasikan maka akan tercipta kemaslahatan bersama untuk para nasabah asuransi syariah.

\section{Karakteristik Akad Asuransi Syariah}

Perusahaan asuransi syariah dalam praktiknya melaksanakan dua fungsi, yang pertama adalah fungsi ta'min taawwuni, kemudian yang kedua adalah fungsi jasa investasi. Saat ini mulai berkembang perdagangan dalam kontrak murabahah. Konsep dasar asuransi syariah adalah saling bertanggungjawab bantu membantu dan melindungi oleh peserta sendiri. Perusahaan asuransi diberi amanah oleh nasabah untuk mengelola premi para peserta asuransi (nasabah), mengelola dana tersebut di jalan yang halal dan memberikan santunan kepada nasabah yang mengalami kesulitan sesuai dengan akad yang telah disepakati. ${ }^{8}$ Ada tujuh karakteristik yang membedakan asuransi syariah dengan asuransi konvensional, yaitu:

Pertama adalah Keberadaan Dewan Pengawas Syariah (yang selanjutnya disebut DPS), yang bertugas mengawasi produk yang dipasarkan dan produk yang ada dalam pengelolaan investasi dana. DPS ditemukan pada asuransi syariah tapi tidak pada asuransi konvensional. Salah satu ciri khas dari karakteristik asuransi syariah adalah adanya adanya DPS sebagai lembaga pengawas penyelenggaraan asuransi syariah, selain Otoritas Jasa Keuangan (OJK). Untuk mengawasi operasional sehari-hari asuransi syariah sebagai salah satu jenis lembaga keuangan syariah agar terhindar dari unsur-unsur gharar, maisir, serta riba maka terdapat DPS. DPS berfungsi untuk melakukan pengawasan secara periodik jalannya operasional sehari-hari agar selalu berjalan sesuai dengan prinsip syariah. DPS ini merupakan bagian yang tidak terpisahkan dari DSNMUI. Adapun yang dimaksud dengan DPS menurut Keputusan Dewan Pimpinan MUI tentang Susunan Pengurus DSN-MUI No. Kep. -98/MUI/III/2001 adalah badan yang ada di lembaga keuangan syariah dan bertugas mengawasi pelaksanaan keputusan DSN di lembaga keuangan tersebut. Tugas dan peran DPS dalam asuransi syariah antara lain: a. Peran utama

\footnotetext{
${ }^{8}$ Machzummy Ibrahim, Dasar-dasar Asuransi Syariah, PP Mardi Mulyo, Jakarta, h. 82.
}

para ulama dalam DPS adalah mengawasi jalannya lembaga keuangan syariah sehari hari agar selalu sesuai dengan ketentuan syariah; b. DPS harus membuat pernyataan secara berkala (setiap tahun) bahwa lembaga keuangan syariah yang diawasinya telah berjalan sesuai dengan ketentuan syariah; c. Tugas lain DPS adalah meneliti dan membuat rekomendasi produk baru dari lembaga keuangan syariah yang diawasinya; d. DPS bersama komisaris dan direksi, bertugas untuk terus-menerus mengawal dan menjaga penerapan nilai-nilai Islam dalam setiap aktifitas yang dikerjakan lembaga keuangan syariah; e. DPS juga bertugas untuk melakukan sosialisasi kepada masyarakat tentang lembaga keuangan syariah, melalui media-media yang sudah berjalan dan berlaku di masyarakat, seperti khutbah, majelis ta'lim, pengajian maupun dialog rutin dengan para tokoh agama dan tokoh masyarakat.

Kedua yaitu Akad yang akan dilaksanakan pada asuransi syariah berdasarkan prinsip tolong-menolong (takaful), sedangkan pada asuransi konvensional berdasarkan akad jual-beli (tadabbuli).

Selanjutnya karakteristik ketiga adalah prinsip perhitungan investasi dana, dimana pada asuransi syariah dasar perhitungan investasi dana berdasarkan prinsip bagi hasil (mudharabah). Pada asuransi konvensional dasar perhitungan investasi dana berdasarkan riba.

Karakteristik yang keempat adalah tentang kepemilikan dana dimana pada asuransi syariah dana investasi yang terkumpul dari peserta (premi) merupakan milik peserta seutuhnya sementara perusahaan asuransi hanya merupakan pemegang amanah atau sebagai pengelola dana (mudharib). Pada asuransi konvensional, dana investasi yang terkumpul dari peserta (premi) menjadi milik perusahaan, sehingga perusahaan bebas menentukan alokasi investasi penggunaan dana.

Kelima, Pembayaran klaim yang dilakukan oleh asuransi syariah diambil dari rekening tabarru' (dana kebajikan) seluruh peserta. Sejak awal menyimpan dana investasinya, peserta sudah diminta keikhlasannya bahwa akan ada penyisihan dana yang akan digunakan untuk menolong peserta lain yang terkena musibah. Sedangkan pada asuransi konvensional pembayaran klaim diambil dari dana milik perusahaan.

Kemudian karakteristik yang keenam adalah keuntungan yang diperoleh perusahaan asuransi. 
Pada asuransi syariah, keuntungan yang diperoleh oleh perusahaan dari investasi dana peserta akan dibagi antara perusahaan dengan peserta sesuai dengan prinsip bagi hasil, dengan proporsi yang telah disepakati bersama di awal. Sedangkan pada asuransi konvensional keuntungan yang diperoleh perusahaan menjadi milik perusahaan seutuhnya.

Karakteristik terakhir adalah kemungkinan adanya dana yang hangus. Pada asuransi syariah tidak mengenal adanya dana yang hangus meskipun peserta asuransi menyatakan akan mengundurkan diri karena sesuatu dan lain hal. Dana yang telah disetorkan tetap dapat diambil kecuali dana yang sejak awal telah diikhlaskan masuk ke dalam rekening tabarru' atau dana kebajikan. Sedangkan pada asuransi konvensional dikenal adanya dana yang hangus jika peserta tidak dapat melanjutkan pembayaran premi dan ingin mengundurkan diri sebelum masa jatuh tempo atau reserving period.

Pembentukan perjanjian asuransi konvensional maupun asuransi syariah pada dasarnya sama dengan pembentukan perjanjian asuransi yang diatur dalam KUHD maupun di dalam BW secara umum, begitu pula standar ketentuan dari isi polis asuransinya. Pada asuransi syariah salah satu landasan hukumnya adalah KUHD, maka prinsip-prinsip yang digunakan dalam pembentukan perjanjian atau akad asuransinya adalah sama seperti asuransi konvensional. Salah satu prinsip pembentukan perjanjian atau akad asuransi adalah sifat konsensuil, sifat ini berarti perjanjian asuransi terbentuk setelah ada kata sepakat antara pihak penanggung dan tertanggung. Hal ini sesuai dengan ketentuan yang ada dalam Pasal 257 ayat (1) KUHD menegaskan bahwa Perjanjian pertanggungan diterbitkan seketika setelah ia ditutup, dan hak-hak dan kewajiban-kewajiban bertimbal balik dari si penanggung dan si tertanggung mulai berlaku sejak saat itu, bahkan sebelum polisnya ditandatangani.

Hal ini dapat diartikan bahwa sifat konsensuil ini mulai mengikat tepat pada saat penanggung dan tertanggung sepakat untuk menutup perjanjian asuransi. Ditandai dengan adanya serangkaian peristiwa yang dilakukan oleh penanggung dan tertanggung, dari kata sepakat sampai dengan pembayaran polis pertama oleh tertanggung dan pembuatan polis yang dilakukan oleh penanggung. Dalam hal ini apabila kedua pihak telah menutup perjanjian (akad) asuransi tetapi polisnya belum selesai dibuat, jika peristiwa tidak pasti terjadi maka tertanggung tetap berhak menuntut klaim ganti rugi. Adapun yang harus dilakukan oleh tertanggung adalah membuktikan bahwa perjanjian asuransi tersebut telah dibentuk. Mengenai pembuktian adanya perjanjian asuransi diatur dalam Pasal 258 KUHD yakni sebagai berikut, untuk membuktikan hal ditutupnya perjanjian tersebut diperlukan pembuktian dengan tulisan, namun demikian bolehlah lain-lain alat pembuktian dipergunakan juga, manakala sudah ada permulaan pembuktian dengan tulisan.

Adapun yang dimaksud dengan polis dalam perjanjian atau akad asuransi, disebutkan dalam Pasal 255 KUHD menegaskan untuk pertanggungan harus dibuat secara tertulis dalam suatu akta yang dinamakan polis. Berdasarkan penjelasan di atas dapat ditarik kesimpulan bahwa keberadaan polis tersebut tidaklah mutlak, yang berarti perjanjian asuransi akan tetap ada walaupun tidak ada polis karena polis bukanlah syarat dalam pembentukan perjanjian asuransi, dasar hukum Pasal 257 ayat (1) jo Pasal 258 KUHD. Adapun fungsi polis: Sebagai dasar pelaksanaan perjanjian asuransi; Sebagai dasar penyelesaian sengketa antara kedua belah pihak, baik sengketa tentang pembentukan maupun pelaksanaan perjanjian asuransi; Sebagai dasar bukti dalam tuntutan ganti rugi yang diajukan oleh tertanggung; Sebagai dasar penghitungan ganti rugi bagi Penanggung.

Sedangkan menurut asuransi syariah yang merupakan bagian dari jelajah hukum perjanjian yang menggunakan akad secara tersendiri menurut hukum Islam, maka dalam sebuah kontrak atau akad harus memenuhi beberapa rukun yang telah ditentukan sebagaimana penjelasan berikut: Shighat al-aqad atau pernyataan untuk mengikatkan diri; $A l-M a$ 'qud alaih/ mahal al-aqd atau objek akad; Al-Muta'aqidain/alaqidain atau pihak-pihak yang berakad; Maudhu alaqd atau tujuan akad.

Shighat al-aqad merupakan cara bagaimana pernyataan pengikatan diri itu dilakukan. Rukun ini adalah merupakan rukun akad yang terpenting. Shighat al-aqad biasanya diwujudkan dalam bentuk ijab dan qabul. Ijab adalah pernyataan pihak pertama mengenai isi perikatan yang diinginkan, sedangkan qabul adalah pernyataan pihak kedua untuk menerimanya. Sesuai dengan bentuknya objek akad atau Al-Ma'qud alaih atau mahal al-aqd bermacam-macam. Agar suatu akad dapat dipandang sah, objeknya memerlukan syarat-syarat antara lain yaitu telah ada pada waktu 
akad diadakan, dibenarkan oleh syara atau nash, dapat ditentukan dan diketahui, dapat diserahkan pada waktu akad terjadi. Rukun berikutnya yang juga merupakan faktor terpenting yaitu pihak-pihak yang melakukan perjanjian (akad). Para pihak ini pun harus memenuhi syarat kecakapan dan kewenangan, hal ini dapat dilihat dalam ketentuan yang ada di BW. Kemudian rukun yang terakhir adalah tujuan akad yaitu tujuan utama mengapa ditentukan adanya akad. Tujuan perjanjian atau Maudhu al-aqd adalah satu meskipun beraneka ragam jenis dan bentuknya sesuai dengan bermacam-macam jenis dan bentuk akadnya.

Sama seperti halnya dalam ketentuan yang ada di syarat sahnya perjanjian pada Pasal 1320 BW, menegaskan bahwa jika salah satu unsurnya tidak terpenuhi maka perjanjian yang dibuat dapat batal demi hukum atau dapat dibatalkan. ${ }^{9}$ Dalam akad asuransi syariah, sebuah akad harus memenuhi empat komponen rukun di atas. Apabila salah satu di antara empat rukun tersebut tidak terpenuhi, maka secara pasti kontrak atau akad yang dilakukan tersebut batal demi hukum atau tidak sah menurut akad perspektif hukum Islam. Pada sebagian besar perusahaan asuransi syariah jenis akad yang digunakan adalah akad tabarru' dan akad tijarah. Akad tabarru adalah semua bentuk akad yang dilakukan dengan tujuan kebajikan dan tolong menolong, bukan semata untuk tujuan komersil. Dimana akad tabarru' yang dimaksud adalah hibah. Dalam akad tabarru' peserta asuransi memberikan hibah yang akan digunakan untuk menolong peserta lain yang terkena musibah, sedangkan perusahaan asuransi bertindak sebagai pengelola dana hibah. Implementasi akad tabarru' dalam sistem asuransi syariah direalisasikan dalam bentuk pembagian setoran premi menjadi dua yaitu rekening tabungan dan rekening tabarru'. Rekening tabungan adalah kumpulan dana yang merupakan milik peserta asuransi. Sedangkan rekening tabarru' merupakan kumpulan dana yang diniatkan oleh peserta sebagai iuran kebajikan untuk tujuan saling membatu dan tolong-menolong. Selanjutnya, dana yang terkumpul dari peserta asuransi akan diinvestasikan oleh perusahan asuransi ke dalam instrumen-instrumen investasi yang tidak bertentangan dengan syariah.

Untuk akad ijarah yang dipilih adalah akad mudharabah. Akad mudharabah merupakan kontrak

\footnotetext{
9 Subekti, Hukum Perjanjian, cetakan kedua puluh satu, Intermasa, Jakarta, 2005, h. 1.
}

kemitraan atau partnership yang berdasarkan pada sistem bagi hasil dengan cara seseorang memberikan modalnya kepada yang lain untuk melakukan bisnis dan kedua belah pihak membagi keuntungan atau profit atau memikul beban kerugian berdasarkan isi perjanjian bersama. Dalam akad mudharabah ini terdapat dua pihak dimana peserta menyediakan $100 \%$ modal sedangkan pihak lainnya menjadi pengelola. Peserta asuransi syariah berkedudukan sebagai pemilik modal dan perusahaan asuransi syariah sebagai pengelola. Keuntungan perusahaan asuransi syariah diperoleh dari bagian keuntungan dana dari para peserta, yang dikembangkan dengan prinsip bagi hasil. Keuntungan yang diperbolehkan dari pengembangan tersebut dibagi antara para peserta dan perusahaan sesuai ketentuan yang telah disepakati oleh pihak nasabah dengan perusahaan asuransi.

Dalam akad mudharabah, mengenal istilah nisbah dan rasio yang berarti proporsi bagi hasil antara perusahaan dan peserta asuransi. Proporsi tersebut sudah ditetapkan di awal perjanjian atau akad, namun yang ditetapkan hanya proporsi berupa perbandingan/ rasio atau prosentase, tidak berupa nilai kas tertentu. Hal ini dilakukan karena besarnya hasil investasi belum diketahui di awal perjanjian atau $a k a d$, karena tergantung besar dan kecilnya hasil yang dipakai oleh perusahaan di kemudian hari. Sistem bagi hasil ini berbeda dengan sistem bunga yang diterapkan dalam perusahaan konvensional. Dalam asuransi syariah yang ditetapkan di awal perjanjian atau akad hanya nisbah atau rasio bagi hasil. Bagi hasil tergantung dari investasi yang dilakukan. Kumpulan dana yang dibayarkan oleh peserta kepada perusahaan asuransi syariah akan diinvestasikan sesuai dengan prinsip syariah. Selain itu perlu diungkapkan bahwa setiap keuntungan dari hasil investasi, setelah dikurangi dengan beban asuransi (klaim dan premi asuransi), akan dibagi menurut prinsip bagi hasil atau almudharabah. Prosentase pembagian tersebut dibuat dalam satu perbandingan tetap berdasarkan perjanjian kerja sama antara perusahaan asuransi syariah dengan peserta. Contohnya 70:30, maka peserta asuransi mendapatkan $70 \%$ keuntungan dan perusahaan asuransi mendapatkan 30\% keuntungan.

\section{PENUTUP \\ Kesimpulan}

Prinsip-prinsip umum dalam praktik asuransi syariah adalah prinsip tauhid, prinsip tolong- 
menolong, prinsip kerja sama, prinsip meringankan beban seseorang, prinsip menghindari gharar, masyir, riba, prinsip risywah, prinsip keadilan, prinsip amanah, dan saling ridho. Secara harfiah prinsip general takaful system adalah prinsip umum jamin menjamin dimana didalamnya ada unsur tolong-menolong, kerjasama dan tentu saja bertujuan meringankan penderitaan atau beban antar sesama anggota asuransi syariah tersebut. Prinsip general takaful system adalah prinsip utama dalam praktik perasuransian syariah. Terdapat 3 prinsip asuransi yang merupakan prinsip general takaful system yaitu prinsip bertanggungjawab, prinsip bekerja sama dan prinsip meringankan beban seseorang. Prinsip ini yang harus diaplikasikan tidak hanya oleh perusahaan asuransi tetapi juga oleh para nasabah atau anggota peserta asuransi syariah.

Jika membahas karakteristik asuransi syariah dibandingkan dengan asuransi konvensional, maka perbedaan yang ada adalah keberadaan DPS yang bertugas mengawasi produk yang dipasarkan dan produk yang ada dalam pengelolaan investasi dana dalam asuransi syariah. Selanjutnya, akad yang dilaksanakan pada asuransi syariah berdasarkan prinsip tolong-menolong atau takaful, dasar perhitungan investasinya berdasar prinsip bagi hasil atau mudharabah. Karakteristik selanjutnya adalah kepemilikan dana, pada asuransi syariah dana investasi yang terkumpul dari peserta (premi) merupakan milik peserta seutuhnya, pada asuransi syariah pembayaran klaim diambil dari rekening tabarru' atau dana kebajikan seluruh peserta, keuntungan yang diperoleh oleh perusahaan dari investasi dana peserta akan dibagi antara perusahaan dengan peserta sesuai dengan prinsip bagi hasil, dengan proporsi yang telah disepakati bersama di awal. Pada asuransi syariah tidak mengenal adanya dana yang hangus meskipun peserta asuransi menyatakan akan mengundurkan diri karena sesuatu dan lain hal. Dana yang telah disetorkan tetap dapat diambil kecuali dana yang sejak awal telah diikhlaskan masuk ke dalam rekening tabarru' atau dana kebajikan.

\section{Rekomendasi}

Saran yang dapat diberikan dalam penelitian ini adalah meningkatkan peran DPS dalam teknis menjalankan perusahaan asuransi syariah, baik melalui aturan yang mengikat ataupun sanksi bagi perusahaan asuransi yang tidak menjalankan prinsip-prinsip asuransi syariah secara utuh. Hal ini agar terjadinya keselarasan antara praktik dengan prinsip-prinsip syariah yang sesuai dengan AlQur'an dan Hadist. Kemudian melakukan kerja sama atau koordinasi yang baik pula dengan OJK sebagai pengawas lembaga keuangan non-bank termasuk dalam hal ini perusahaan asuransi syariah. Memberikan transparansi kepada para nasabah asuransi terkait dengan investasi dana yang ada di perusahaan asuransi. Agar tidak ada kesalahpahaman dan diharapkan dapat meningkatkan kepercayaan nasabah dengan perusahaan asuransi.

\section{DAFTAR PUSTAKA}

\section{Peraturan Perundang-undangan:}

Al-Qur'an dan As-sunnah.

Burgerlijk Wetboek (BW).

Kitab Undang-Undang Hukum Dagang.

Undang-Undang Nomor 40 Tahun 2014 tentang Perasuransian.

Peraturan Menteri Keuangan RI No. 18/ PMK.010/2010 tentang Penerapan Prinsip Dasar Penyelenggaraan Asuransi dan Usaha Reasuransi dengan Prinsip Syariah.

Keputusan Menteri Keuangan RI No. 422/ KMK.06/2003 tentang Penyelenggaraan Usaha Perusahaan Asuransi dan Perusahaan Reasuransi.

Keputusan Menteri Keuangan RI No. 424/ KMK.06/2003 tentang Kesehatan Keuangan Perusahaan Asuransi dan Perusahaan Reasuransi.

Keputusan Menteri Keuangan RI No. 426/ KMK.06/2003 tentang Perizinan Usaha dan Kelembagaan Perusahaan Asuransi dan Perusahaan Reasuransi.

\section{Buku:}

Anshori, Abdul Ghofur. 2008. Asuransi Syariah di Indonesia. Yogyakarta: UII Press.

Dewi, Gemala. 2004. Aspek-aspek Hukum dalam Perbankan dan Perasuransian Syariah di Indonesia. Jakarta: Kencana.

Ibrahim, Machzummy. Dasar-dasar Asuransi Syariah. Jakarta: PP Mardi Mulyo.

Ismanto, Kuat. 2009. Asuransi Syariah (Tinjauan Asas-Asas Hukum Islam). Yogyakarta: Pustaka Pelajar.

Marzuki, Peter Mahmud. 2008. Penelitian Hukum. Jakarta: Kencana Prenada Media Group. 
Muslehuddin, Muhammad. 1999. Menggugat Asuransi Modern. Jakarta: Lentera.

Prakoso, Djoko. 2004. Hukum Asuransi Indonesia. Jakarta: Rineka Cipta.

Sastrawidjaja, M. Suparman. 1997. Aspek-Aspek Hukum Asuransi dan Surat Berharga. Bandung: Alumni.

Subekti. 2005. Hukum Perjanjian. cetakan kedua puluh satu. Jakarta: Intermasa.
Makalah:

Buku Saku Lembaga Bisnis Syariah. Pusat Komunikasi Ekonomi Syariah (PKES).

Sumber Brosur Karakteristik Asuransi Syariah yang dikeluarkan oleh Asuransi Syariah Bumiputera.

\section{Website:}

www.pesankonsumen.com//hukum asuransi dalam praktik, diunduh pada tanggal 15 Februari 2015. 